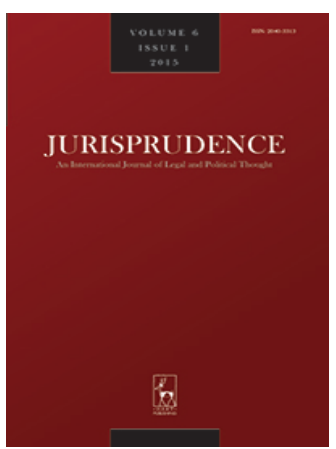

Jurisprudence

An International Journal of Legal and Political Thought

ISSN: (Print) (Online) Journal homepage: https://www.tandfonline.com/loi/rjpn20

\title{
Disagreement about the kind law
}

\section{Muhammad Ali Khalidi \& Liam Murphy}

To cite this article: Muhammad Ali Khalidi \& Liam Murphy (2020): Disagreement about the kind law , Jurisprudence

To link to this article: https://doi.org/10.1080/20403313.2020.1787783

$$
\text { 曲 Published online: } 13 \text { Jul } 2020 .
$$

Submit your article to this journal $₫$

Q View related articles $₫$

View Crossmark data ־ 


\title{
Disagreement about the kind law
}

\author{
Muhammad Ali Khalidi ${ }^{\mathrm{a}}$ and Liam Murphy

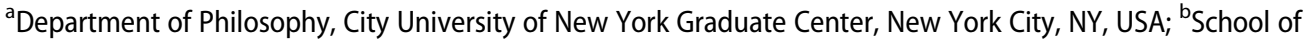 \\ Law and Department of Philosophy, New York University, New York City, NY, USA
}

\begin{abstract}
This paper argues that the disagreement between positivists and nonpositivists about law is substantive rather than merely verbal, but that the depth and persistence of the disagreement about law, unlike for the case of morality, threatens skepticism about law. The range of considerations that can be brought to bear to help resolve moral disagreements is broader than is the case for law, thus improving the prospects of reconciliation in morality. But the central argument of the paper is that law, unlike morality, is a concept-dependent social kind, in the sense that law cannot exist in a society without someone in that society having the concept of law. Since the existence of the social kind law is largely dependent on the existence of the corresponding concept, when different actors have different concepts, they can end up creating different kinds. Hence, the difference between positivists and nonpositivists is not just a conceptual one but is capable of giving rise to different legal norms.
\end{abstract}

\section{Introduction}

Philosophical disagreement about the nature of law seems particularly obdurate. But is it less tractable than other deep-seated disagreements, such as those about morality? And does persistent disagreement about the nature of law suggest that there may be no truth to be found, though that is not so for the case of morality? In this paper, we argue that the dispute between positivists and nonpositivists about the nature of law is different mainly because law is a social kind that depends on our concepts.

If we assume that there are such things as 'social kinds', that is natural kinds in the social domain, we can go on to ask about the nature of these kinds. ${ }^{1}$ In particular, in what ways do social kinds depend on human concepts, beliefs, and actions? To better understand the nature of the disagreement between positivists and nonpositivists, this paper will examine the nature of law through the lens of social kinds. We will argue that law is a particular kind of social kind, one whose existence is dependent on our having a concept of it. This claim illuminates the nature and implications of the

\footnotetext{
CONTACT Liam Murphy liam.murphy@nyu.edu

${ }^{1}$ Social kinds are sometimes contrasted with natural kinds, but we don't intend the 'natural' in 'natural kind' to provide a contrast with the social. In our view, natural kinds are more aptly labelled, 'real kinds', and are not restricted to the domains of the natural sciences. This is in keeping with the original use of 'kinds' in the nineteenth century, by philosophers like Mill, Whewell, and Venn, all of whom thought that kinds could be found in the social domain; for further justification of this account of social kinds, see Muhammad Ali Khalidi, Natural Categories and Human Kinds (CUP 2013). 
disagreement between positivists and nonpositivists and helps explain why it is intractable. Along the way we will discuss some other legal kinds, showing how they are similar to and different from law itself. This inquiry into law and other legal kinds is at once epistemological and metaphysical, since we will argue that in these cases, a society's possessing a certain concept is necessary for having the corresponding social kind.

We begin in Section 2 by characterising the disagreement between positivists and nonpositivists about law; we contrast it with disagreement about morality in Section 3. The discussion of the dispute about the nature of law in Section 2 is of necessity simplified and somewhat dogmatic. We do not take ourselves to have fully defended our characterisation of the dispute in this essay. The aim is rather to set the stage for the discussion of law through the lens of social kinds that follows in Section 4, where we argue that law is a concept-dependent social kind, one whose existence depends on the existence of the corresponding concept. The implications of this conclusion for the dispute between positivists and nonpositivists about the nature of law are discussed in Section 5.

\section{Disagreement about law}

In the Rhetoric, Aristotle distinguishes between the 'written law', which is specific to a particular place, and the unwritten 'common law', which is the same everywhere and expresses what is just by nature (1373b). He then advises anyone arguing a case before an Athenian jury to exploit this distinction. The law governing the dispute could be thought to be grounded either entirely in the written law, or alternatively in the written law as corrected by the common law. Where the written law is against you, you should argue from the common law, pointing out that the written law does not always 'perform the function of law'. Where the written law is on your side, you should remind the jury that their job is not to try to be 'wiser than the laws' (1375a-1375b). The advice is to lean on one or another way of understanding what kind of thing Athenian law is, depending on which understanding better suits your case.

These two ways of understanding what the law is roughly correspond to the distinction between positivism and nonpositivism. We can say that positivists believe that what the law is, is a matter of a nonevaluative reading of the legal materials; whereas nonpositivists insist that the legal materials must always be interpreted in the light of general moral principles which are also part of law. ${ }^{2}$ This is a debate that is characterised by a very striking level of partisanship. Each side thinks the other fundamentally misguided and finds their arguments obviously hopeless. What are we to make of this?

On one view, it is no accident that Aristotle discusses the issue in the Rhetoric. Yes, there is an ambiguity in our ordinary talk of law, but that is only important because we need to be on the lookout for devious legal arguments. We don't need to settle on one or the other of the options as correct. When we come across strategic appeal to one way of understanding law or the other we can simply refuse to play along: we can drop law-talk, and talk about something else.

\footnotetext{
${ }^{2}$ Here, as warned, we are simplifying greatly. We ignore so-called 'inclusive' or 'soft' positivism and treat the position of Ronald Dworkin in Law's Empire (Harvard UP 1986) as the canonical nonpositivist view, ignoring other options. For further discussion, see Liam Murphy, What Makes Law (CUP 2014).
} 
In particular, those charged to make a decision in accordance with law, such as an Athenian jury or a modern judge, don't need a theory of how to determine the content of law (a theory of the 'grounds of law' in Ronald Dworkin's terminology ${ }^{3}$ ). They just need a theory of how to make decisions, a theory of adjudication. Those who hold a positivist theory of law generally accept that since law as they understand it will not always yield a determinate answer to a particular dispute, a judge may have to go outside the law in order to reach a result. In the typical case, that will involve appealing to moral considerations. Positivists can even agree that to every legal dispute that comes before a court, there is a best resolution and that moral judgment is often required to reach it. They just disagree that the law as it is prior to adjudication already contains a determinate answer. Since positivists and nonpositivists can agree about what judges should do, some think that their disagreement about how to determine the content of law is unimportant.

This first reaction to the dispute between positivism and nonpositivism is to treat it as purely verbal. ${ }^{4}$ We don't need to resolve it because it doesn't matter - we can carry on discussing anything that matters without using the idea of the content of the law already in force. This eliminativist view has recently been advanced by Lewis Kornhauser, and has been endorsed by others. ${ }^{5}$ The idea is that we can discuss what judges should do when deciding cases, as well as how subjects and officials ought to act in light of political decisions reflected in the content of legal materials, and also what our aspirations for a mode of governance we might call legal should be - all of this (and more) we can do without advancing propositions about the content of the law.

The eliminativist position seems implausible for denying either the reality or the importance of law as a distinct normative domain. We do lose something important if we stop talking about the content of the law. At the very least law's content has expressive significance within a political community. But it also has practical significance. A purely selfinterested person might plausibly conclude that it is in her long-term self-interest to comply with her best understanding of what the law requires. And for many people, especially those with official roles in government, what the law requires is of considerable moral importance. 6

In any event, our discussion of the social kind law is premised on the common sense assumption that there is, in fact, a real normative order of law in our society and that it matters. There are many true propositions about the content of the law in force and it can be important to know what they are. We also take it as fundamental that the legal normative order is a distinct normative order, not just a taxonomic subpart of some other normative order, such as conventional or critical (true) morality. We thus reject the position that Ronald Dworkin took towards the end of his career that legal rights and obligations are just certain kinds of moral rights and obligations. If that were so, there would be no interesting question to ask about the ontological status of the legal order in particular.

\footnotetext{
${ }^{3}$ See Dworkin, Law's Empire (n 2).

${ }^{4}$ See David Chalmers, 'Verbal Disputes' (2011) 120 Philosophical Review 515.

${ }^{5}$ See Lewis Kornhauser, 'Prescindir del concepto de Derecho' in M Alegre (ed), El Imperio de Ronald Dworkin: Ensayos de Filosofia Moral, Politica y Juridica (Eudeba 2019), which is a translation of the working paper 'Doing without the Concept of Law', available at SSRN: https://ssrn.com/abstract=2640605 or https://doi.org/10.2139/ssrn.2640605. See also Murphy, What Makes Law (n 2) 88-102.

${ }^{6}$ See Liam Murphy, 'The Normative Force of Law: Individuals and States' in John Gardner, Leslie Green and Brian Leiter (eds) Oxford Studies in Philosophy of Law, Vol 3 (OUP 2018).
} 
But this view expressly denies the reality of law as a distinct normative order and so to us is implausible on its face. ${ }^{7}$

So we take for granted that legal norms are not just moral norms, and that the normative order to which they belong is not one we should start simply to ignore. It matters that we be able to determine the content of the law. And so the disagreement between positivism and nonpositivism about the grounds of law is a disagreement that matters. ${ }^{8}$

What then, about the fact that the state of the dispute seems to be one of permanent stalemate? The situation seems to be one where each side is committed to a foundational picture of what kind of thing law is and the chance that any substantive argument will persuade anyone to cross the aisle is negligible.

For a positivist, the legal normative order is one that is grounded in social fact. Perhaps any legal order is in some way good; good ones certainly are. But to start figuring out what the law is by thinking about what it would be good for it to be is to confuse quite distinct kinds of normative order. But there's your mistake, reply the nonpositivists. What you miss is that law in its nature is something good, or can be seen as striving towards being something good - or at the very least, is something that can't be very bad. Moreover, the evident truth that law is something good, or at least potentially so, is tied up with the further evident truth that the law is genuinely binding on us, or is usually so, or is in some sense meant to be so. To see law as ultimately grounded in social fact is to miss these essential moral qualities of law.

Old-fashioned conceptual analysis by way of appeal to key examples is not going to help with this clash of pictures, because each side is going to react differently to the test cases. There have been arguments that have the right form for moving beyond the standoff though we are aware of only two of them. Both arguments proceed by linking the concept of law to another concept, with the hope that agreement about the reality of the link, and about the other concept, will lead people to revise their views about law. One argument, by Dworkin, links law to the concept of legality; the other, by Raz, links law to the concept of authority. ${ }^{9}$ Without going through the details, it seems to us that though the arguments move us away from mere brute intuitions about what law is, each argument nonetheless contains premises that will seem incredible to those in the grip of the opposing picture.

The disagreement, we believe, is so fundamental that the prospects of any convergence seem minimal. It is tempting, in the face of this, to revert to the thought that the dispute is purely verbal. If nothing either side can say will engage the other side in substantive debate, that certainly raises the suspicion that there is nothing substantive at stake. And

\footnotetext{
${ }^{7}$ See Ronald Dworkin, Justice in Robes (Harvard UP 2006) 34, and Justice for Hedgehogs (Harvard UP 2011) 405-07. See also Mark Greenberg, 'The Moral Impact Theory of Law' (2013-14) 123 Yale LJ 1288; Greenberg, 'The Moral Impact Theory, the Dependence View and Natural Law' in George Duke and Robert George (eds), The Cambridge Companion to Natural Law Jurisprudence (CUP 2017); Nicos Stavropoulos, 'Legal Interpretivism' in Edward Zalta (ed), The Stanford Encyclopedia of Philosophy (Summer 2014 Edition) URL $=<$ https://plato.stanford.edu/archives/sum2014/entries/law-interpretivist/>. Dworkin and Greenberg both have a hard time providing intuitively plausible taxonomic criteria to identify those moral norms that are legal norms. If the matter were just taxonomic, nothing much would turn on this. Their difficulty, however, is symptomatic of the fundamental objection to the It's-All-Morality view: that it denies the reality of law as a distinct normative order with its own internal criteria that determine what is 'legal' and what is not.

${ }^{8}$ The expressive and practical importance of knowing the content of the law in force is not the only possible reason why the debate might matter, though we believe it is the most important. One might believe that knowledge about the nature of law, in particular whether moral considerations are among the grounds of law, has intrinsic importance.

${ }^{9}$ Dworkin, Law's Empire (n 2); Joseph Raz, 'Authority, Law, and Morality' in Joseph Raz, Ethics in the Public Domain (OUP 1995).
} 
yet, when we review the reasons why it seems to matter what the law is, they seem just as strong as they ever were. Statements about the content of the law in force seem to be a central, and ineliminable, feature of everyday social discourse.

It would be hard to understand how this combination of a commitment to it mattering what the content of the law is and intractable disagreement about how to figure that out could persist in social life, were it not for a further crucial fact: Despite the intractable disagreement about the grounds of law, the two positions yield the same conclusions about particular legal propositions in the vast majority of cases.

Since one view holds that moral considerations are never relevant to determining law and the other that they always are, this claim may seem incredible, especially in countries where individual rights are constitutionally enshrined. For example, some people believe that the Equal Protection Clause of the 14th Amendment to the United States Constitution enacts, as part of U.S. law, a moral principle of equal treatment: 'government must treat everyone as of equal status and with equal concern'. ${ }^{10}$ Others believe that the equal protection clause authorises the Supreme Court to decide, outside the boundary of law, whether legislation violates its view of what morality requires in the domain of equal protection. ${ }^{11}$ As there is no agreement on the right way to understand the Equal Protection Clause, and as all law must satisfy that clause, do we not face the result that there is no law in the United States at all? If there is no way to resolve the disagreement between those who believe that adjudication of equal protection issues takes place at least in part outside the law and those who believe it all happens within law's boundary, it may seem to follow that there will never be agreement about whether any particular piece of legislation is, or is not, valid law.

But that's not so, since frequently it makes no difference whether moral factors are considered to be within law's boundary or not. No one thinks that the law against murder violates equal protection, or that only marriage between persons of the same sex is constitutionally permissible in the United States. Though some insist that these conclusions depend in part on moral reasoning and others deny it, their truth doesn't depend upon agreement about why they are true. There is, moreover, partial agreement about why they are true. The overlapping consensus does not apply only to lowest level legal conclusions; it applies also to a good many of the factors that are relevant to reaching such conclusions. All plausible views hold that such legal sources as validly enacted statutes, judicial decisions, and constitutional provisions are among the grounds of law. Against this background of agreement, disagreement about the place of moral factors is in practice not always significant.

Of course, there are also disagreements about how to interpret such legal sources and what weight to give them. But again, in a significant range of cases, those favouring moral readings of sources, and a moralised approach to the doctrine of stare decisis, can end up in the same place as positivists who offer a straight-forward nonmoral interpretation.

\footnotetext{
${ }^{10}$ Ronald Dworkin, Freedom's Law (Harvard UP 1996) 10.

${ }^{11}$ 'If the argument here advanced is sound then it follows that the function of courts to apply and enforce the law coexists with others. One is authoritatively to settle disputes, whether or not their solution is determined by law. Another additional function the courts have is to supervise the working of the law and revise it interstitially when the need arises. In some legal systems they are assigned additional roles which may be of great importance. For example, the courts may be made custodians of Freedom of Expression, a supervisory body in charge both of laying down standards for the protection of free expression and adjudicating in disputes arising out of their application'. Raz, 'Authority, Law, and Morality' (n 9) 217.
} 
The overlap between different accounts of the concept of law allows us to resolve the tension between the conviction that it is important to be able to determine the content of the law and the conviction that the dispute between competing accounts of how to do that, competing accounts of the content of the concept of law, is intractable. While the intractable nature of the dispute does not in itself establish that there is no truth of the matter to be had here, it does, as we have said, suggest it - more so than for similarly intractable moral disputes, as we will discuss in the next section. If we conclude that there is no truth of the matter to be had but just an ambiguity, we could say that where a proposition of law comes out as true for both concepts of law, it is true; where it is false for both concepts, it is false. ${ }^{12}$ Where there is no overlap among the plausible concepts, it is indeterminate whether the proposition of law is true, false, or neither.

This suggestion is analogous to the so-called 'supervaluation' approach to vague terms such as 'bald'. ${ }^{13}$ Vague terms have borderline cases - there are a range of numbers of hairs on a man's head where it is indeterminate whether he is bald or not. The supervaluation approach counts sentences using vague terms as true (or false) when they are true (or false) on all the different plausible precisifications of the concept. ${ }^{14}$ This is only an analogy, since the concept of law is not vague; the problems we have been discussing do not concern borderline cases but different accounts of what can be relevant to determining whether a legal proposition is true. Different plausible accounts of the concept of law do not propose different ways of making the concept more precise, but different accounts of the grounds of law. It is therefore more accurate to say that the concept of law is ambiguous, though the various plausible disambiguations overlap considerably, as we have seen. ${ }^{15}$ In this regard, the term 'law', as used by positivists and nonpositivists, can be compared to the ambiguous verb 'report', which has overlapping factive and non-factive interpretations. Consider the sentence, 'The police reported that the culprit had fled'. On the factive reading, what the police said is true, whereas on the non-factive reading, it need not be. ${ }^{16}$ Similarly, nonpositivists presuppose that legal conclusions reflect moral reasoning and have moral implications, while positivists do not.

Normally, ambiguity raises no particular philosophical puzzle. It is always possible to disambiguate - to say, for example, that you meant by 'bank' the financial institution. The ambiguity of the concept of law raises problems because the ambiguity is not generally recognised and because there are important obstacles in the way of any general practice of disambiguation. ${ }^{17}$ Government officials use the concept of law without any suggestion that it is ambiguous. And most of the rest of us do so too. Most people, if asked by a legal

\footnotetext{
${ }^{12}$ In a non-simplified account, we would replace 'both concepts' with 'all plausible concepts'.

${ }^{13}$ Thanks to Kit Fine and Paul Horwich for this observation.

${ }^{14}$ On supervaluation, see Kit Fine, 'Vagueness, Truth and Logic' (1975) 30 Synthese 265; David Lewis, 'Many, But Almost One' in John Bacon, Keith Campbell and Lloyd Reinhardt (eds), Ontology, Causality, and Mind: Essays on the Philosophy of D.M. Armstrong (CUP 1993).

${ }^{15}$ Since 'law' is ambiguous rather than vague, the supervaluation approach to it is not affected by the objection to the supervaluation approach to vagueness that it implies that vague concepts do after all, at least in a certain sense, have precise boundaries (which, intuitively, they do not). For criticism of the supervaluation approach to vagueness, see Timothy Williamson, Vagueness (Routledge 1994).

${ }^{16}$ This example derives from Arnold M. Zwicky and Jerrold M. Sadock, 'Ambiguity Tests and How to Fail Them' (1975) 4 Syntax and Semantics 1. They survey a number of tests that linguists have devised to distinguish ambiguity from non-specificity (which is roughly equivalent to vagueness), but they also note that it is difficult to apply the tests when the meanings are closely related as in this case (and we would add, as in the case of the concept of law).

${ }^{17}$ Since we have argued that 'law' is ambiguous, strictly speaking, there are two concepts of law rather than one, but we will sometimes speak loosely of 'the concept of law'.
} 
philosopher which of the various possibilities they had in mind when they made some statement about the law, would not know how to answer. ${ }^{18}$ Even if the various possible views became well-known, the obstacles to disambiguation are plain. Acceptance of a general practice of case by case disambiguation - where participants, when pressed, would say for example that they meant that such and such was the law in the positivist sense - would be a radical departure from our current practice that assumes the general availability of univocal answers to questions of what the law is (even if the answer is that it is indeterminate). And convergence on just one of the options is unlikely because of the deep entrenchment of both pictures of law in the culture.

What we have, with the concept of law, is a case of what David Lewis calls 'semantic indecision'. But it is an indecision of a particular sort: as a group of language users, and participants in the practice of law, we have neither decided on one of the plausible disambiguations of 'law' nor accepted that it is ambiguous and thus helped ourselves to the practice of case-by-case disambiguation. And given both the contestedness of the concept and the practical demand for a practice that does not require case-by-case disambiguation, we can be sure that a decision will never be made. ${ }^{19}$ The proposed response to this situation is well brought out in these remarks of Lewis:

What shall we do, if semantic indecision is inescapable, and yet we wish to carry on talking? The answer, surely, is to exploit the fact that very often our unmade semantic decisions don't matter. Often, what you want to say will be true under all different ways of making the unmade decision. Then if you say it, even if by choice or by necessity you leave the decision forever unmade, you still speak truthfully. It makes no difference just what you meant, what you say is true regardless. And if it makes no difference just what you meant, likewise it makes no difference that you never made up your mind just what to mean. ${ }^{20}$

So we can go on talking to each other about law even though our concept of law is ambiguous because, for a great range of cases, that ambiguity does not matter. But now what about the range of cases, in some jurisdictions certainly not negligible, where the moral stakes are high and so the two accounts of the concept of law do not overlap? Here the ambiguity matters in that it results in there being no fact of the matter about what the law requires. But does it matter that there are such cases? In professional legal practice, perhaps not so much. Lawyers can still give predictive advice and judges can use their theory of legal decision-making without worrying about whether, in doing so, they are applying or making law. And for citizens too, the realisation that the truthvalue of some legal propositions cannot be determined without first disambiguating the concept of law is not so terribly threatening to our self-understanding of the importance of law to our relationship to the state, and through it to others. It is one thing to say that, for some subset of legal propositions, there is no answer to the question of whether they are true, false, or neither; quite another to say that this is the case for all legal propositions.

To sum up the stage-setting claims of this section: there is intractable disagreement about the content of the concept of law, which can lead to intractable disagreement

\footnotetext{
${ }^{18}$ This is because most people, most of the time, only consider those propositions of law that fall within the overlap among reasonable views. Those who do consider and argue about 'hard cases', such as legal academics, appellate lawyers, and judges, are certainly aware of the ambiguity.

${ }^{19}$ For some relevant discussion of the differences between vagueness, ambiguity, and contestedness, see Jeremy Waldron, 'Vagueness in Law and Language: Some Philosophical Issues' (1994) 82 California LR 509.

${ }^{20}$ Lewis, 'Many, But Almost One' (n 14) 28-29.
} 
about how to determine the content of the law in force. But this is not in tension with the widespread sense that propositions of law are important and are very often either true or false. The overlap between the two views leaves many, probably the great majority, of propositions of law capable of truth or falsity. We do, however, have to acknowledge that for some cases there is no fact of the matter about whether a proposition of law is true, false, or neither.

\section{Disagreement about morality}

This partially skeptical result may seem to be acceptable for the case of law. But if so, that must tell us something about the kind law. For consider disputes about a different normative order: morality. Just as for law, though there is considerable overlap in ground-level moral conclusions across different moral theories, the overlap is not complete. And the disagreement among adherents of different moral theories is certainly deep and persistent. The most obvious example would be disagreement between orthodox consequentialism and any moral theory according to which there are, in addition to agent-neutral reasons to make things go better in general, agent-relative reasons not to treat people in certain ways. ${ }^{21}$ Listen to certain consequentialists and you can come away with the distinct sense that further substantive argument is not going to change their minds, at any rate.

We said that paradigm cases are not going to help with the disagreement between positivists and nonpositivists because each side will react differently to the cases. For some consequentialists, it's just the same. Give them an example of killing one to distribute organs to save five and their response is that in principle that would be OK. People naturally think it would not be, they add, but that's because of a very beneficial aversion most people have to killing, and a very reasonable sense that a social policy that allows that kind of thing would be overall suboptimal because of the level of anxiety it would produce. And so on.

So there seems to be just as deep disagreement among moral theories as there is among legal theories. ${ }^{22}$ But in the case of morality, the suggestion that we treat moral propositions on which plausible moral theories give divergent verdicts as having no truth value seems preposterous. The persistence of disagreement about morality just doesn't seem to justify that skeptical conclusion.

But there are two important differences between law and morality. The first is that the range of relevant related considerations that can be drawn into moral argument, to move us beyond brute intuitive reaction to the simplest test cases, is immensely wider than is the case for law. The factors that we might want to throw into the reflective equilibrium pot are unlimited. It's true that the two most celebrated arguments about the nature of law proceed, as already noted, by considering what law has to do with other connected matters. But there are just vastly more other matters that fundamental moral questions interact with. Thus, when thinking about whether consequentialism is plausible, we can think about what that implies for our actions, our dispositions, the design of the basic structure of society. And there is much scope for new good ideas challenging or crystalising or supporting our initial beliefs. Suppose we are inclined to think that there are rights, but worry that there should be something that could be said other than that they

\footnotetext{
${ }^{21}$ On the two kinds of reasons, see Thomas Nagel, The View From Nowhere (OUP 1986) chs 8 \& 9.

${ }^{22}$ We are grateful to Samuel Scheffler for pressing the point.
} 
seem to exist. There are some things. Kant's idea that it is wrong to disrespect the agency in other people by treating them as a mere means is one idea. Or we might find illuminating Scanlon's idea that fundamental questions of how we can treat one another are best understood in terms of a process of justification where we ask whether a principle that allows us to do something is one that others could reasonably reject. ${ }^{23}$ Despite the undeniable fact that there are a few doctrinaire moral theorists, and despite the fact that Bernard Williams is probably right that there is little prospect for moral convergence on a single fully worked out moral theory, ${ }^{24}$ it is not the case that the prospects for substantive moral argument changing people's prior positions are negligible.

So one reason why we should react to deep disagreement in legal theory more skeptically than in the case of moral theory is that the field of connected issues is so much wider and deeper on questions of right and wrong and this gives us much greater reason to expect that further argument will emerge that will move things along.

But in the remainder of this essay, we will explore a different difference between the two cases: the fact that law is a particular kind of social kind. By contrast, morality is either not a social kind at all (on a realist view) or a different kind of social kind (on a conventionalist account). The consequence is that what law is, but not what morality is, is in large part up to us. Where the nature of a social kind is up to us, persistent disagreement threatens the reality of the kind.

\section{Law and the concept of law}

Joseph Raz has argued that there can be law in a society that has no concept of law. ${ }^{25}$ Raz justifies his position with reference to one example in particular, that of independent Jewish communities governed by religious law:

Whenever theocratic autonomous Jewish communities existed or may exist they would be subject to law, i.e. Jewish religious law. But the concept of law is not part of the Jewish religion, and where such communities existed in the past they often existed in societies whose members did not possess the concept of law. ${ }^{26}$

Though this is a compelling illustration, we think that a strong case can be made for the opposing view. Like Raz, we agree with Hart that there cannot be law in a society unless certain people, legal officials, accept legal rules and principles as guides to action. ${ }^{27}$ But Raz holds that all that is necessary is that officials accept the rules, not that they accept them as rules of law. ${ }^{28}$ This seems right if we are discussing law in a broad sense, one that would include conventional morality or mores, religious law, or some kind of rule by moral philosophers enforcing what they regard to be the truth about right and wrong. But the dispute between positivists and nonpositivists over what determines the content of law is a dispute about positive law in an institutionally complex society. Perhaps it makes sense to say that traditional customary law enforced by elders, or religious law enforced

\footnotetext{
${ }^{23}$ TM Scanlon, What We Owe to Each Other (Harvard UP 1998).

${ }^{24}$ Bernard Williams, Ethics and the Limits of Philosophy (Harvard UP 1985).

${ }^{25}$ 'Can There Be a Theory of Law?' in Martin P Golding and William A Edmundson (eds), The Blackwell Guide to the Philosophy of Law and Legal Theory (Blackwell 2005).

${ }^{26}$ ibid 336.

${ }^{27}$ See HLA Hart, The Concept of Law (3rd edn, OUP 2012) 115.

${ }^{28}$ 'Can There Be a Theory of Law?' (n 25) 335-36.
} 
by clerics, are legal systems too; and perhaps it makes sense to say that even if the elders or clerics have no concept of law. But the issue of what determines the content of law in such societies is very different than it is in societies in which law is for the most part made by political officials and institutions. It is here that the clash between positivism and nonpositivism gets its bite. In other words, the debate between positivists and nonpositivists is a debate about how to understand a normative order that all agree to be distinct from religious normative orders, conventional morality, and objective or ('critical') morality, and that all agree, moreover, has something to do with political decisions made within the society. It is against that background of agreement that the disagreement about the grounds of law makes sense. ${ }^{29}$

There are features of the concept (positive) law, and indeed of the kind (positive) law, that make it unlikely that a full-fledged order of law would emerge in the absence of the concept of law. An order of positive law requires practices of law-making and legal decision-making even if those practices do not exhaust the grounds of law. In the canonical Hartian positivist picture, a socially accepted rule of recognition is necessary for the identification of law; such a rule is precisely a set of criteria to distinguish laws from non-laws. ${ }^{30}$ In the canonical nonpositivist position of Dworkin in Law's Empire, the content of law is a matter of moralised interpretation of legal materials that requires at least a provisional, 'pre-interpretive', initial identification of the legal materials. ${ }^{31}$ Possession of criteria that distinguish instances from non-instances, is on many accounts of concepts, necessary for possessing a concept. ${ }^{32}$ Merely distinguishing instances from noninstances of law may not be sufficient for having the concept of law, but doing so reflectively on the basis of criteria would seem to be a weak sufficient condition for possessing the concept of law. Furthermore, in the case of law, reflective application of criteria in a social setting will inevitably have an effect on social practices. This does not mean that everyone situated in a community with law needs to possess the concept of law, nor that those who do possess the concept always agree on its application; all that is required is that some people must possess it and to some extent converge in their judgments of application. Without this much, it is hard to see how a distinct normative order of law, as opposed to conventional morality, or etiquette, could emerge.

In this respect positive law is different from etiquette, conventional morality (or morality itself on a nonrealist view that reduces it to social practice), or religious law. Those normative orders could exist without anyone having the corresponding concepts. In addition to Raz's example, consider H.L.A. Hart's well-known discussion of a 'pre-legal' normative order comprising primary obligations only - it has no secondary rules of change, adjudication, and recognition. ${ }^{33}$ We take no stand on whether such a normative order should be thought of as a legal order or not. But if it should, it seems clear that its

\footnotetext{
${ }^{29}$ This leaves aside, obviously, the 'It's-All-Morality' position of the late Dworkin and Greenberg. But that position lies outside the traditional dispute between positivism and nonpositivism in any case, as it is not a position about the grounds of law but rather about how to classify different types of moral norms.

${ }^{30}$ Hart, The Concept of Law (n 27).

${ }^{31}$ Dworkin, Law's Empire (n 2) 91-92.

${ }^{32}$ Many theories in philosophy and cognitive science link concept possession to discriminative and recognitional capacities, see e.g. Christopher Peacocke, A Study of Concepts (MIT Press 1992) and Ruth Millikan, On Clear and Confused Ideas (CUP 2000). Such theories are not without their critics, see e.g. Jerry Fodor, Concepts: Where Cognitive Science Went Wrong (OUP 1998), but we cannot justify this theoretical stance in the scope of this paper.

${ }^{33}$ The Concept of Law (n 27) 91-99.
} 
existence does not require anyone to have the (broad) concept of law. As in Raz's case, all that would be required would be acknowledgement by at least some people of the existence of certain rules. The case of positive law is different because it is part of the core of the concept of positive law that all share that it is a distinctive normative order, distinct in particular from mores, religious law, and critical or conventional morality.

Some people need to possess the concept law for the kind to exist, but which people, and how many? It would seem that at least most people involved in legal decisionmaking, enforcement, and expert interpretation should possess the concept, for otherwise the distinct normative order of positive law would lack stability. Some of these people could be acting blindly, not reflecting on just which rules they were employing in their reasoning, but the greater the number of people in that situation, the more likely would be the disintegration of positive law into something else, such as a conventional moral order. At the limit perhaps it is enough if one person in a society possesses the concept for the kind to exist, but in such a case the kind would not be expected to exist for very long.

The question of the relationship between social kinds and their corresponding concepts has been tackled in more general terms by philosophers of social science who have distinguished social kinds whose existence does not depend on the existence of the concept in the community in question and those whose existence does so depend. The first type of social kind can be labelled 'concept-independent' and the latter 'concept-dependent'. We can also distinguish a third type of social kind, namely a subset of the second type whose individual instances depend on someone applying the concept to each of them. While the second type are such that the kind is concept-dependent, the third type are such that each individual instance of the kind is concept-dependent; equivalently, we can say that the third type of kind is application-dependent. Thus, we can distinguish three kinds of social kinds by asking two questions. First, does the existence of the kind depend on someone having the concept of it? Second, does the existence of instances of the kind depend on someone applying the concept to them? ${ }^{35}$ There are cases where the answer to both questions is no. Amie Thomasson suggests racism, recession, and superstition $^{36}$; other examples might include art, poverty, and inflation. There can be poverty in a society where no one ever has thoughts about poverty, where, put otherwise, we may say the concept of poverty does not exist. Similarly for racism. Though for there to be racism there must be people with prejudiced attitudes to certain groups, there needn't be any beliefs or attitudes about racism as such. This is not true for the second type of social kind, kinds such as money, since for something to function as money the people who use it need to have attitudes towards that category. It is true that money could emerge in a community gradually without anyone having conceptualised it as such. In a barter economy, we might start to use some commodity as a medium of exchange without thinking of it as such. The practice might creep up on us unawares and we might not notice the

\footnotetext{
${ }^{34}$ Although she does not label them as such, the first articulation of the distinction between these two kinds of social kinds seems to occur in Amie Thomasson, 'Foundations for a Social Ontology' (2003) 18-19 Protosociology 269. When it comes to concept-dependent kinds, we take it that possessing the concept is a necessary but not sufficient condition for the existence of the social kind. Spelling out a set of sufficient conditions for the existence of any given social kind may not be possible, and is anyway not required for our argument.

${ }^{35}$ For further discussion, see Muhammad Ali Khalidi, 'Three Kinds of Social Kinds' (2015) 90 Philosophy and Phenomenological Research 96.

${ }^{36}{ }^{\prime}$ Foundations for a Social Ontology' (n 34) 276.
} 
fact that, say, cowrie shells have become primarily a means of storing value rather than a commodity to be used. But the practice is unlikely to persist for long without it being acknowledged as such. That is why it is plausible to say that one cannot have money without the concept of money. When it comes to this second type, however, individual instances of the kind do not depend on people having propositional attitudes towards them. Arguably, a particular token of money may be money while no one thinks it is or thinks anything about it at all. Though this example may be disputed, Searle asks us to consider the case of a $\$ 10$ bill that falls from the printing press through the cracks in the floorboard. It is still an instance of the kind money, even though no one has thought of it as such. ${ }^{37}$ Another example of the second type of kind might be war, since it is also plausible that war proper, as opposed to wide-scale violence, depends on our having the concept of it, along with traditional concepts such as a declaration of war, ceasefire, and so on. But it is possible, and perhaps in recent decades typical, that a particular conflict might break out and evolve into a war without any kind of acknowledgement as such. These cases illustrate the fact that, when it comes to the second type of social kind, one cannot have the kind without the concept but one can have particular instances of the kind without anyone having recognised them as such.

The third type of social kind answers yes to both questions: not only is the kind itself concept-dependent, but its instances are also concept-dependent. Some highly conventional categories, such as prime minister or permanent resident, might qualify for this third category: you can't be one unless you are regarded as satisfying the criteria to be one. This seems to be a feature of many institutional social kinds, whose instances become instances of the kind only upon some more or less official application of the concept to them.

We have made a case, against Raz, for regarding (positive) law as belonging at least to the second type, but should one go further and classify it in the third type? And what about other legal kinds, such as contract, jury, murder, and felon? Some legal kinds do seem to belong to the third type of social kind. We have already mentioned permanent resident. Even if a person satisfies the legal criteria for permanent residency in principle, she will not be a permanent resident unless a relevant official determines that she is. A legal system cannot have juries without someone having a concept of jury, but neither can a particular group of people constitute a jury without someone recognising them as such (for example, a judge). Similar considerations seem to pertain to felon. Even if a person has committed a felony, it seems that the concept of felon is only applied if the legal system has determined that that is what he is. This case may be contested, however, since the practice of referring to people as 'convicted felons' suggests that one can be a felon though not convicted. More clearly in the second rather than the third category is murder; the idea of 'getting away with murder' and our commonsense description of certain people as murdering with impunity presupposes that one can be a murderer though never formally identified as such. Should we go so far as to say a murder can be committed if no one has the concept of murder? No, unlike killing, murder seems to be a type-two kind: a society with an accepted practice of intentional revenge killings would not be rightly described as one where murder is rife. As these cases of felon and murder already make clear, the assignment of particular social kinds to types will sometimes be controversial, difficult, or context-dependent.

${ }^{37}$ John Searle, The Construction of Social Reality (Free Press 1995) 32. 
An interesting class of cases comes from private law. What to say about contract will depend on the jurisdiction. In the United States, one can make an agreement with no thought one way or the other about its legal enforceability that is nonetheless a contract legally speaking; this means that there can be particular contracts no one has ever identified as such. This is not possible in most other jurisdictions, where at least a tacit intent to enter legal relations (to make a legally enforceable contract, rather than just exchange promises) is a requirement for there to be a contract - so at least the parties must identify the agreement as a contract for it to be one. Even in the United States, however, it is clear that someone must have the concept of a contract for there to be contracts, since the concept of a contract directs us to the law for further guidance on what a contract is. So contract is concept-dependent, and in most jurisdictions also application-dependent.

Just as in the case of law, however, there are wider and narrower concepts of contract. The wider concept encompasses not just legally enforceable agreements but also contracts with God or the devil, the social contract, and the idea of 'having a contract' on someone an agreement that, despite its name, everyone knows is not legally enforceable. In this wider sense, 'contract' seems to be synonymous with 'agreement' or 'deal'; it is an interesting and difficult question whether there can be agreements or promises in a society in which these concepts do not exist. The answer will turn upon whether Hume is right that promissory morality is artificial, in his technical sense. This is a difficult issue that would take us too far afield. ${ }^{38}$

Take next property. No one can own anything in a society that lacks a concept of property. Property is concept-dependent. This is so both for a narrow legally-tied concept of property, and a wider, informal one. Whether legally formalised or not, property is a set of rules about who can do what with certain things. This would be true even if property were not necessarily dependent on convention. Suppose that Locke's naturalistic labour theory of property were plausible. Even if that were so, if nobody had any ideas about rightful use, exclusion, and so on, with respect to possessions, there would be no stability of possession and it would be impossible to say who owned what; there would be no property in that society.

Is property also application-dependent? Someone may own something even though no one now knows that she does. A bank account was opened in her name when she was a child; she was never told, the person who opened the account is now dead, and the only record of the account is some paper file at the local bank that no has looked at in years. This is not yet a case of application-independence, however, for someone once did apply the concept of property to the account. Under the law of inheritance in some jurisdictions, such as Germany, ownership passes to heirs at the moment of death without the need for an intermediate owner such as an executor. ${ }^{39}$ And so it is possible under (some) rules of intestate succession that a distant and unknown relative of a person who died without a will became an owner of an estate though no one ever knew that she did. As for contract, then, whether or not narrowly legal property is application-dependent will depend in part on the content of the law. On the other hand, and unlike the case of contract, it seems that for the looser, informal concept of property not tied to any particular legal order, property seems to be application-dependent. Some complex legal

\footnotetext{
${ }^{38}$ On Scanlon's view of promising, in What We Owe to Each Other ( $\mathrm{n} 23$ ) ch 7, there can be promises without the concept promise. Others disagree. For discussion, see Liam Murphy, 'The Artificial Morality of Private Law: The Persistence of an Illusion' University of Toronto $\amalg$ (Advance Online). doi:10.3138/utlj.2019-0103.

${ }^{39} \S 1922$ BGB.
} 
apparatus seems to be necessary for us to be able to make sense of someone owning something even though no one ever applied the relevant concept to that thing.

What now about law itself? We are considering, recall, the content of the positive law, of what the law around here requires. Can a legal proposition be true if nobody regards it as true? It can; law is application-independent. For example, there can be widespread interpretive error about the content of the law. Everyone may have missed that the way in which a section of a statute has been interpreted puts it in conflict with the clear meaning of another section. It is sometimes suggested that the law is what a judge says it is, which would in turn suggest that law is application-dependent. But that view would entail that a newly enacted statute is not a source of law until interpreted by a judge. It would also entail that judicial error was not possible. The idea that the law is what a judge says it is should be rejected, and generally is, by both positivists and nonpositivists. It is true that, for a positivist, we can't all be wrong about all of law. But mistakes by some but not all officials about all of law, or by some or all officials about some of law, are certainly possible; as Hart argued, law is not like a game of scorer's discretion. ${ }^{40}$ For nonpositivists, there can in addition be widespread legal mistakes that turn on normative error. So we can agree that particular instances of the kind are not concept-dependent. It is true that legislation needs to be enacted, and hence conceptualised as law, and that judicial decisions only count as sources of law if the court is recognised as a court of law. Nonetheless, on both positivist and non-positivist understandings, each individual legal proposition need not be recognised as law for it to be law. Therefore, law is not a type-three kind. But law is, as we have argued, a type-two kind. There can be no positive law in a community that lacks the concept; law is concept-dependent, and this matters.

\section{Implications for the positivism-nonpositivism debate}

At least some people have to apply the concept of law if law is to be a distinct normative order, distinguishable from etiquette, conventional morality, religious law, and so on. But now if there are no legal propositions if no one has any propositional attitudes about legal propositions, then what legal propositions are and can be is partly up to us. Only partly, because presumably there cannot be legal requirements to do the humanly impossible, for example, so facts about what is humanly possible will constrain the possible content of law. But it is partly up to us. At least it is up to us to fix what kinds of decisions by what kinds of institutions contribute to the content of the law in force. And it seems furthermore to be up to us how those decisions contribute to the content of the law in force. To say that what legislatures do contributes to the content of law is not very helpful if we don't have views about which things they do count, and how they count. We may know that certain documents are statutes and statutes are sources of law, but if we don't know how to read them, we are not very far along. ${ }^{41}$

If no one ever applies the concept of law in order to determine the content of the positive law, there is no positive law. You cannot accept certain rules and principles as guides to action if you have no view about the content of those rules and principles. Now of course people do apply a concept of law to identify grounds of law. The trouble is that

\footnotetext{
${ }^{40}$ See Hart, The Concept of Law (n 27) 141-47.

${ }^{41}$ See Ronald Dworkin, 'The Model of Rules I' in Taking Rights Seriously (Harvard UP 1977).
} 
we don't all have the same view. Some think it is crucial to give a straight, nonmoralized interpretation of the legal materials; others disagree.

Suppose a difference of opinion arose about what cocktail parties are. Some hold that it can't be a cocktail party if funds are being raised for a political candidate. Others disagree. The only sensible thing to conclude is that there are two kinds of cocktail party in our society. It is fine if there are two kinds of cocktail party. The trouble with law is that we all assume that there is only one kind. So the presence of two views about how to identify the rules seems to threaten the very existence of the kind.

Now of course it is possible that the disagreement between positivists and nonpositivists is only superficial. Deep down, we all agree, or as Raz would put it, we share the same concept. ${ }^{42}$ But it is this hope that apparently intractable disagreement about the grounds of law seems to undermine. It seems that the only hope for convergence lies in conversion. If we all start to see the law as positivists do, then positivism will be true. If we all start to see the law as nonpositivists do, nonpositivism will be true.

Given that it does not seem to be plausible that there is a bedrock of agreement to be found beneath the superficial disagreement, arguments between positivists and nonpositivists are successful only if they succeed. What Hart said about changes in the rule of recognition is also true about the argument about the grounds of law. All that succeeds is success. ${ }^{43}$ This gives renewed plausibility to Bentham's and, following him, Hart's instrumental way of thinking about the dispute. ${ }^{44}$ Giving instrumental reasons why it would be better if we were all positivists is an entirely valid form of argument. ${ }^{45}$ The problem with that kind of argument isn't that it confuses what is with what ought to be, but that it won't succeed because people won't convert. ${ }^{46}$

There is a sense, then, that what law is is a matter of what people currently think it is. There isn't a fact of the matter, or a deep structure to the concept of law, that can correct those superficial beliefs. This gives persistent disagreement about law a different status from persistent disagreement in the context of moral argument. It is what justifies reacting to persistent disagreement about law with skepticism about law itself. This doesn't mean that the nature of law is entirely at the mercy of our concept of law, since as with other social kinds, the law is liable to evolve and be transformed in ways that we do not fully intend or even anticipate. Although there is an element of stipulation in many social kinds of the second and third type, even these kinds can end up getting away from us to some extent. We have argued that law is concept-dependent, but our 'manifest concept' of law may not coincide with our 'operative concept' - to use a distinction made by Sally Haslanger. ${ }^{47}$ The manifest concept is the concept that we take ourselves to

\footnotetext{
${ }^{42 ‘}$ Authority, Law, and Morality' (n 9) 237.

${ }^{43}$ Hart, The Concept of Law (n 27) 147-54.

${ }^{44}$ ibid 200-12; 'Positivism and the Separation of Law and Morals' in Essays in Jurisprudence and Philosophy (OUP 1983) contains relevant references to Bentham.

${ }^{45}$ Perhaps the best expression of this line of thought comes from Hans Kelsen, who writes that nonpositivism 'tends towards an uncritical legitimisation of the political coercive order ... for it is presupposed as self-evident that one's own political coercive order is an order of law'. 'Law and Morality' in Ota Weinberger (ed), Essays in Legal and Moral Philosophy (Reidel 1973) 92. More recent defenders of the instrumental approach include Frederick Schauer, 'The Social Construction of the Concept of Law: A Reply to Julie Dickson' (2005) 25 OJLS 493 and David Plunkett, 'Negotiating the Meaning of "Law": The Metalinguistic Dimension of the Dispute over Legal Positivism' (2016) 22 Legal Theory 205.

${ }^{46}$ For further discussion, see Murphy, What Makes Law (n 2) 73-76.

${ }^{47}$ See Sally Haslanger, 'What Good Are Our Intuitions? Philosophical Analysis and Social Kinds' (2006) 80 Proceedings of the Aristotelian Society 89.
} 
be applying to the cases in question, whereas the operative concept is the one that best captures the distinction as we draw it in practice. When it comes to the concept law, we may take ourselves to be applying it in ways that don't quite coincide with the way we actually apply it. Therefore, the law itself may not conform in every respect to what we take our concept law to be. For example, positivists may intend that the content of law depend not at all on morality, but yet find that, in their actual practice of interpretation, it does so. Still, the nature of law depends in large measure on our concept of it and attitudes towards it, so positivists will tend to find positivist law and nonpositivists nonpositivist law.

This conclusion is only compatible with the conviction that it matters what the law is, that we cannot simply drop talk of legal propositions without loss, because of the considerable overlap among plausible concepts of law. For the vast run of cases, as we saw, the two sides agree about how to determine the law in force. The crucial propositional attitudes converge. There there is law, and it is important to know what it is.

The area where the deep disagreement matters is the area where the truth or falsity of legal propositions carries high moral stakes in a legal community or where the plain meaning of the legal materials is indeterminate. In that area, we have to accept that, pending convergence one way of the other, there is no answer to questions about the content of law. So we will have to talk about something else, such as what a judge should do if a case comes before her.

\section{Conclusion}

In this paper, we have argued that the disagreement between positivists and nonpositivists about law is a substantive one and, moreover, is importantly different in two respects from disagreements about morality. The first respect is that the range of considerations that can be brought to bear to help resolve moral disagreements is much broader, thus improving the prospects of reconciliation in morality by comparison with law. The second respect concerns the nature of law as a social kind. Law is a concept-dependent social kind, in the sense that law cannot exist in a society without someone in that society having the concept of law. Since the kind law is largely dependent on the concept of law, when different actors have different concepts, they end up creating different kinds. Hence, the difference between positivists and nonpositivists is not just at the level of discourse; it has ramifications for the respective kinds that they create. Unlike conceptual differences about morality, which do not have the power to generate different objective moral standards (at least on realist views), conceptual differences about the law are capable of giving rise to different legal norms.

\section{Acknowledgements}

We are grateful to Lewis Kornhauser, Stephen Neale, and anonymous reviewers for comments. The support of the Filomen D’Agostino and Max E. Greenberg Research Fund of New York University School of Law is gratefully acknowledged.

\section{Disclosure statement}

No potential conflict of interest was reported by the author(s). 